\title{
Population Dynamics of Bean Leaf Beetle, Cerotoma trifurcata (Coleoptera: Chrysomelidae) on Edamame Soybean Plants In Nebraska
}

By

\author{
${ }^{a}$ Bamphitlhi Tiroesele*, 'Thomas E. Hunt, \\ ${ }^{\mathrm{b}}$ Robert Wright and John E. Foster.
}

\begin{abstract}
Edamame soybeans are a speciality food item for fresh and processed markets and they are harvested at a physiologically immature (R6) stage. Bean leaf beetle, Cerotoma trifurcata, is a sporadic pest of soybean in Nebraska, however, its pest status and abundance has increased in the recent years due to an increase in soybean acreage. This was a field experiment aimed at determining the population growth rate of bean leaf beetle on two edamame soybean cultivars, 'Butterbeans' and 'Envy,' at two planting dates during 2004 and 2005 in Nebraska. The population growth of beetles was significantly higher on 'Butterbeans' than on 'Envy' for both the first and second planting periods in both 2004 and 2005 seasons. The beetle infestation differences were noticed on plants at the late reproductive growth stages, R5 and R6. Additionally, the beetle infestation on 'Butterbeans' growth stages in 2004 and 2005 was significantly different for the first and second planting dates. On average, the beetles were higher on plants at the late reproductive stages than the other stages for first and second planting periods. Similarly, 'Envy' growth stages showed significant difference in beetle infestation during the first and second planting dates. Significantly high beetle infestations were observed at the vegetative growth stages. The study revealed that population growth of bean leaf beetles on edamame soybeans is affected by the planting date, season and cultivar choice.
\end{abstract}

Key words: Edamame, Butterbeans, Envy, Cerotoma trifurcata, planting date

\section{Introduction}

Edamame is a vegetable soybean that is increasing in popularity in the U.S. as a result of the high nutritional value and health benefits. These soybeans are harvested and eaten when pods (seeds) are fully filled and still at the immature stage (Reproductive stage 6). Fresh or frozen edamame soybeans are consumed

${ }^{a}$ Department of Crop Science and Production, Botswana College of Agriculture, Private Bag 0027, Gaborone, Botswana

bDepartment of Entomology, University of Nebraska-Lincoln, Lincoln, NE 68583-0816

cDepartment of Entomology, University of Nebraska Haskell Agricultural Laboratory, Concord, NE 68728-2828

*Corresponding author 
just like green peas (Pisum sativum). The pods are boiled and the beans added to stews, mixed vegetables, soups and stir-fried vegetables. These soybeans are well known in Asian countries such as China (Guan, 1977), Japan (Benziger and Shanmugasundaram, 1995), and Korea (Hong et al.,1984). Edamame soybeans are distinct from regular grain soybeans in many ways such as having large seeds with mild taste, tender, and also easily digestible. Fresh green soybeans also have been reported to have a combination of low oil and relatively high protein content (Brar and Carter, 1993) and also contain a lower percentage of gas-producing starches. It has been found that harvesting vegetable soybeans at the right time is important for maximum texture and flavor (Johnson, 2000; Wszelaki et al., 2005), because loss of quality occurs when pods turn yellow.

Soybean has many insect pests limiting its production, including, the bean leaf beetle. The bean leaf beetle (BLB), Cerotoma trifurcata (Forster) (Coleoptera: Chrysomelidae), is endemic to North America and it has been historically regarded in the mid-western United States as a relatively minor pest which can occasionally cause economic losses in soybeans, Glycine max. Hunt et al. (1994) determined that leaf defoliation of $68 \%$ in seedling soybeans caused $12 \%$ reduction in yield. Bean leaf beetle feeding also can cause up to $40 \%$ soybean pod damage (Witkowski \& Echtenkamp 1996). This insect has been reported to be a sporadic pest of soybean in Nebraska, however, its pest status, abundance and significance has increased in the recent years primarily due to the rapid increase in soybean acreage (Srinivas et al., 2001). There are many factors which can affect the beetle population increase and these include environmental conditions, overwintering success, cultural practices, natural enemies, cultivar planted and the synchronization of soybean and beetles development (planting date). The BLB adults overwinter in field crop residue and in forest leaf litter (Lam et al., 2002). In the spring the adults exit the overwintering sites and move to available hosts such as alfalfa. The adults colonize soybeans as soon as the first seedlings emerge and throughout their early vegetative stages. The insect has two generations per year in Nebraska (Witkowski and Echtenkamp. 1996). Bean leaf beetle is the pest most associated with pod injury on a regular basis in the Midwest. This insect chews smooth-edged, round holes in newly expanded leaves and pods reducing yield and seed quality. It may feed on blossoms and stems. Its larvae feed on roots, nodules and the underground stem. The beetle is capable of transmitting diseases such as bean pod mottle virus (BPMV). Adult bean leaf beetles feed mostly on leaves and pods, with the most serious losses caused by pod feeding. Pod lesions caused by the beetles allow excess moisture and secondary plant disease organisms to enter the pod (Obopile and Hammond, 2001), causing seed shriveling and discoloration. As a result, the seed quantity and quality are reduced. The first increase in bean leaf beetle, population for the first generation is associated with 
foliar feeding and the second generation with seed and pod feeding (Hammond et al., 1991).

BLB is one of the pests of concerns of soybeans (Koch et al., 2012). Hence, there is a need to develop and evaluate integrated pest management tactics for this pest (Carrillo et al., 2005). Effective alternative means of soybean pest management are needed to reduce insecticide applications and the ensuing economic and environmental costs in soybean production systems (Hesler et al., 2012). An understanding of the phenology of this pest is essential in the development of a successful pest management program. Important applications of this information include improved timing of scouting procedures and proper implementation of management tactics (Smelser and Pedigo, 1991). Host plant phenology also affects the distribution and abundance of herbivores by producing a temporal variation in host quality. Insect herbivores often adapt to this temporal variation in resources by synchronizing their life cycles with the phenologies of the host plants. Dawn et al. (1999) reported that modification of planting dates has been widely used to disrupt synchrony between crops and pests. Although the population fluctuations and biology of bean leaf beetle on grain soybean has been studied (Lam et al., 2001), there is lack of information about their behavior and possible management practices on edamame soybeans. The knowledge of the infestation times of bean leaf beetle on these soybeans can help to manage them more especially in avoiding seed damage at harvestable stages. The modification of crop phenology can result in reduction of insect numbers and injury per insect. Such changes include planting alternative varieties, changing planting dates, or both. The objective of this study was to describe the population dynamics of bean leaf beetle adults on 'Butterbeans' and 'Envy' edamame soybean cultivars and relate insect densities to the different growth stages of these two cultivars. The study also examines the differences in pod damage caused by bean leaf beetle between the two cultivars at different planting dates.

\section{Materials and Methods}

\subsection{Study site}

A field experiment was conducted at the University of Nebraska-Lincoln's Agricultural Research and Development Center near Ithaca, Nebraska in 2004 and 2005. The field was surrounded by tall trees, shrubs and grasses on three sides and the other side was corn and soybean field.

\subsection{Experimental design and planting}

The experiment was arranged in a completely randomized design and was carried out twice in each of two years (2004 and 2005), with two planting dates each year. The treatment design was a $2 \times 2$ factorial, with cultivar and plant growth stage as 
the factors. Two edamame soybean cultivars, 'Envy' (64 days to harvest) and 'Butterbeans' (75 days to harvest), were planted, and the plants were observed at each of 8 possible developmental stages (V5 to R6 growth stages). The soybean vegetative (V5 and V6, fifth and 6th node with fully developed leaves, respectively) and reproductive growth stages (R1: beginning bloom, R2: full bloom, R3: beginning pod, R4: full pod, R5: beginning seed, and R6: full seed stage, respectively) were identified according to Fehr et al. (1971). In each planting date/year combination, each cultivar was replicated twice.

These cultivars were planted at two different planting dates to investigate the seasonal occurrence of bean leaf beetle. A $35 \mathrm{~m}$ x $47 \mathrm{~m}$ field area was divided into two parts corresponding to two planting dates for 2004 and 2005. The two cultivars were each planted in four row plots measuring $3 \mathrm{~m}$ by $9 \mathrm{~m}$. A $1.5 \mathrm{~m}$ width strip of sweet corn (Zea mays L.) was planted at the margins of the field. This planting pattern was adopted throughout the experiment. The two planting dates were separated by $8 \mathrm{~m}$ wide strip, which was also planted in sweet corn to provide a buffer between plots.

Plots were seeded on 20 May and 3 June in 2004 and on 18 and 31 May in 2005. Planting was done at a rate of 371,000 seeds/ha. The distance between the seeds was $3.6 \mathrm{~cm}$, and the rows were $75 \mathrm{~cm}$ apart. Bean leaf beetle infestation in the experimental plots occurred naturally. Plots were hand-weeded once every year when soybeans were at V5 growth stage to reduce the effects of weed competition.

\subsection{Data collection}

The bean leaf beetle adult counts per plant were done twice weekly from the day they began to appear (V3 growth stage for early planted soybean and V1 growth stage for late planted soybean) up to soybean reproductive stage R6, when edamame soybean is typically harvested. Sampling was done between 1000 and 1500 h. Soybean developmental stages were recorded on each sampling date. Data collection was done by in-situ observation (visual counts on the plant) of insects on the plant. The bean leaf beetle numbers were determined by counting those present on ten randomly selected plants per row in a plot. Counts were taken from two inner-rows in a plot. The first 20 and last 20 plants in each row were not sampled to avoid field margin effects.

Bean leaf beetle pod damage was assessed at the end of the R6 stage for each variety when pods started to change to a yellowish color. This was done by randomly picking five plants per row in each plot. Ten pods from each selected plant were randomly chosen in 2004 and 20 pods in 2005. Each pod was then assessed and evaluated visually for bean leaf beetle damage on a 0 to 5 score (Aruna et al., 2005) $(0=$ plants with no pod damage, $1=\leq 5 \%$ pod damage, $2=$ 
$\leq 10 \%$ pod damage, $3=11$ to $\leq 20 \%$ pod damage, $4=21$ to $\leq 40 \%$ pod damage and $5=\geq 41 \%$ pod damage).

\subsection{Data analysis}

The experimental data were analyzed as a split-plot design with cultivar as the main plot factor and developmental stage as the sub-plot factor. Population densities of bean leaf beetles were analyzed using the PROC MIXED procedure (SAS Institute, 2004) to test for interactions between cultivar and developmental stage. When statistically significant interactions were present, simple effects of cultivar and plant stage were estimated and tested at the 5\% level. In the absence of a statistically significant interaction, main effects of cultivar and plant stage were estimated and tested at the 5\% level. Both main and simple effects were estimated using the LSMEANS option in PROC MIXED. The analysis was carried out separately for each planting date/year combination.

\section{Results and Discussion}

Bean leaf beetle began to be observed at the same time (mid-June) for both 'Butterbeans' and 'Envy' and also for both planting dates even though the varieties were at different growth stages.

\section{Effect of early planting edamame soybean on bean leaf beetle infestation}

The average number of bean leaf beetle per plant through R6 growth stage for the first planting date was significantly higher on 'Butterbeans' $(1.08 \pm 0.06)$ than on 'Envy' $(0.71 \pm 0.15)$ in $2004\left(\mathrm{~F}_{1,56}=22.96 ; \mathrm{P}=0.0001\right)$ and similarly higher on 'Butterbeans' $(0.87 \pm 0.03)$ than 'Envy' $(0.53 \pm 0.04)$ in $2005\left(\mathrm{~F}_{1,48}=48.29 ; \mathrm{P}=\right.$ 0.0001) (Table 1). Bean leaf beetle were first observed on 'Butterbeans' during the vegetative growth stage 3 (V3) for both years. However, the beetles first appeared on 'Envy' during first planting date at vegetative growth stage V4 (Table 2). 'Butterbeans' was significantly higher in the number of bean leaf beetle per plant than 'Envy' at most growth stages in $2004\left(\mathrm{~F}_{8,56}=4.31 ; \mathrm{P}=0.0004\right)$ and $2005\left(\mathrm{~F}_{8}\right.$, ${ }_{56}=8.65 ; \mathrm{P}=0.0001$ ) (Table 2). Therefore, yield or quality of 'Butterbeans' is likely to be affected by the bean leaf beetle infestation more than 'Envy'.

The bean leaf beetle infestation levels among the 'Butterbeans' growth stages per plant were significantly different in $2004\left(\mathrm{~F}_{8,31}=21.56 ; \mathrm{P}=0.0001\right)$ and $2005\left(\mathrm{~F}_{8,71}=24.20 ; \mathrm{P}=0.0001\right)$ (Table 2$)$. One population peak was observed on 'Butterbeans' which occurred from V3 growth stage (Mid June) to R1 growth stage (Table 2). The population of bean leaf beetle was observed to distinctly increase at the R7 growth stage at the end of August (results not shown here). R6 is the growth stage at which edamame soybean is harvested, so timely harvesting can reduce or avoid damage by the second population increase. 
Additionally, there was a significant difference in average populations of bean leaf beetle among "Envy' growth stages during the first planting date in 2004 $\left(\mathrm{F}_{8,25}=29.14 ; \mathrm{P}=0.0001\right)$ and $2005\left(\mathrm{~F}_{8,59}=51.73 ; \mathrm{P}=0.0001\right)$ (Table 2). The beetle population increased and reached the highest peak levels near R1 (blooming stage) in 2004 and at R1growth stage in 2005. 'Envy' plants experienced one bean leaf beetle population peak period. This could be because they matured early as compared to the 'Butterbeans'. By the time the resurgence of bean leaf beetle occurred late in the season, 'Envy' plant leaves were maturing showing yellowing and reddish coloration. There were no beetles found on 'Envy' plants after R6 stage. The plant quality was deteriorating and also less attractive for bean leaf beetle.

\section{Effect of late planting edamame soybean on bean leaf beetle infestation}

Bean leaf beetle mean numbers were significantly different between 'Butterbeans' and 'Envy' cultivars in $2004\left(\mathrm{~F}_{1,62}=31.40 ; \mathrm{P}=0.0001\right)$ but it was not significantly different in $2005\left(\mathrm{~F}_{1,146}=25.50 ; \mathrm{P}=0.97\right)$ for the late planting date. There were significantly higher beetle infestation on 'Butterbeans' $(1.34 \pm 0.05)$ than on 'Envy' (0.91 \pm 0.07) in 2004 and similarly higher beetle infestation on 'Butterbeans' ( $0.76 \pm 0.04)$ than on 'Envy' $(0.62 \pm 0.04)$ in 2005(Table 1).

In the 2004, the beetles infestation among 'Butterbeans' growth stages per plant were significantly different $\left(\mathrm{F}_{10,31}=17.32 ; \mathrm{P}=0.0001\right)$. 'Butterbeans' plants experienced two beetle population peaks. The first peak was near V3 growth stage and V4 growth stage (Table 3). The bean leaf beetle populations declined from R1 growth stage (beginning bloom) to R4 growth stage (Full pod). The second peak population occurred at R6 growth stage. In 2005, 'Butterbeans' growth stages showed significant differences $(\mathrm{F}=36.93 ; \mathrm{df}=10,77 ; \mathrm{P}=0.0001)$ in the average beetle population per plant (Table 3). Two population peaks were observed on 'Butterbeans' that was planted late. The first beetle population peak was observed around the V3 growth stage and V4 growth stage. The second population peak was seen at the R5 growth stage (seed filling) and R6 growth stage (full seed). This second population peak on 'Butterbeans' is likely to affect the beans quality and quantity if timely harvesting is not done.

Similarly, bean leaf beetle infestation levels per plant among the 'Envy' growth stages were significantly different in $2004\left(\mathrm{~F}_{10,31}=16.19 ; \mathrm{P}=0.0001\right)$ and in $2005\left(\mathrm{~F}_{10,69}=51.80 ; \mathrm{P}=0.0001\right)$. However, unlike the 'Butterbeans', 'Envy' was not infested by the second peak population in 2004 and 2005 when planted late (Table 3) and it was only infested by low numbers of second generation beetles in 2005 at R6 growth stage (0.64 \pm 0.07$)$. 'Envy' only had a single peak population which occurred around V2 growth stage $(1.70 \pm 0.22)$ and V4 growth stage $(1.70 \pm 0.16)$ in 2004 and around V5 in 2005 (1.38 \pm 0.11$)$ (Table 3). The second generation beetles were found to continue to increase in 2005 beyond R6 
(Data not shown). The beetle populations per plant were very low, particularly starting from R1 growth stage through R6 growth stage.

The average number of bean leaf beetles per plant between 'Butterbeans' and 'Envy' growth stages for late planting period were significantly different in $2004\left(\mathrm{~F}_{10,62}=5.12 ; \mathrm{P}=0.0001\right)$ and $2005\left(\mathrm{~F}_{10,146}=25.93 ; \mathrm{P}=0.0001\right)$ (Table 3). 'Butterbeans' infestations by bean leaf beetle at V1, R3, R5 and R6 growth stages in 2004 second planting date were found to be significantly higher than on 'Envy'. In 2005 late planted plants, 'Butterbeans' at V4, R4, R5 and R6 growth stages were also observed to be significantly higher in the number of bean leaf beetles per plant compared to 'Envy' (Table 2). However, 'Envy' showed higher beetle infestations than 'Butterbeans' at V5, V6 and R1 growth stages. 'Butterbeans' had some green leaves and pods later in the season, which were a likely source of attraction to bean leaf beetle. Baur et al. (2000) reported that maturity group of a soybean plant can influence the abundance of insect pests. When cultivars of differing maturities are present, insects will often prefer one cultivar over another.

The first beetle population peak that was experienced by both cultivars, both in 2004 and 2005, is not likely to affect the soybean growth and development as it has been reported that vegetative soybeans are capable of withstanding extensive defoliation before they suffer serious economic injury (Fehr et al., 1981; Hunt et al., 1994). Soybeans can also compensate for defoliation by producing excess leaves (Higley and Boethel, 1994). The increase in bean leaf beetle populations near R4, R5 and R6 growth stages is likely to affect yield and quality by damaging the pods. Damage through pod feeding that occurs during R4 growth stage to R6 growth stage is most likely to cause yield losses (Hammack et al., 2010). Therefore, 'Butterbeans' are more likely to be affected by bean leaf beetle than 'Envy'.

\section{Pod Damage by Bean Leaf Beetle}

There was no significant difference in pod damage between 'Butterbeans' and 'Envy' both in $2004\left(\mathrm{~F}_{1,18}=2.70 ; \mathrm{P}=0.12\right)$ (Fig. 1) and 2005 (F1, $38=3.75 ; \mathrm{P}=$ 0.06) (Fig. 2) during the first planting date. This is because plants for both 'Butterbeans' and 'Envy' did not experience the second generation bean leaf beetle infestation. During the second planting date, 'Butterbeans' had significantly more damage compared to 'Envy' in $2004\left(\mathrm{~F}_{1,18}=6.43 ; \mathrm{P}=0.02\right)$ (Fig. 1) and $2005\left(\mathrm{~F}_{1,38}=36.69 ; \mathrm{P}=0.0001\right)$ (Fig. 2), because it was infested by the second generation of bean leaf beetles. The 'Butterbeans' continued to have green vegetative growth even at the R6 growth stage and likely attracted more beetles than 'Envy'. The pod damage comparison of 'Butterbeans' planted early and late showed that late planted 'Butterbeans' are significantly more damaged than early planted ones $\left(\mathrm{F}_{1,18}=9.56 ; \mathrm{P}=0.006\right)$. A similar pattern was observed on early and late planted 'Envy' plants $\left(\mathrm{F}_{1,18}=4.93 ; \mathrm{P}=0.04\right)$. Therefore, soybean pod 
damage was significantly higher on late planted plants than early planted plants. The population pattern between the early and late planted plants for both cultivars is similar for 2004 and 2005.

It has been observed in this study that time of planting can be utilized to avoid impacts of bean leaf beetle populations on 'Butterbeans' and 'Envy'. When 'Butterbeans' and 'Envy' are planted early, they mature early before the occurrence of second beetle population peak. However, only 'Envy' was able to avoid attack by the second peak of the bean leaf beetle population when planted late. This study also shows that choice of cultivar can help to reduce the impacts of bean leaf beetle infestations. 'Envy' was not highly infested by bean leaf beetle at the critical growth stages for both the early and late planting dates as compared to 'Butterbeans'. Timely harvesting of these cultivars can also help reduce the damage caused by bean leaf beetle.

\section{Conclusion}

This research revealed that planting date and cultivar choice, based on maturity period, can affect the bean leaf beetle population growth on edamame vegetable soybeans. The use of early maturing cultivars and early planting can be recommended when the bean leaf beetle populations are likely to increase as the season progress. 'Butterbeans' which is late maturing attracted more bean leaf beetle than 'Envy' (early maturing) for both planting periods in 2004 and 2005. The difference was more evident at late reproductive growth stages, R5 and R6, where 'Butterbeans' had higher beetle population growth than 'Envy' for both planting periods. It can, therefore, be hypothesized that the difference in the beetle population levels between the two cultivars may be the result of their physiological differences.

\section{References}

Aruna, R., Rao, D. M., Reddy, L. J., Upadhyaya, H. D. and Sharma, H. C. 2005. Inheritance of trichomes and resistance to pod borer (Helicoverpa armigera) and their association in interspecific crosses between cultivated pigeon pea (Cajanus cajan) and its wild relative C. scarabaeoides. Euphytica 145: 247-257.

Baur, M. E., Boethel, D. J., Boyd, M. L., Bowers, G. R., Way, M. O., Heatherly, L. G., Rabb, J. and Ashlock, L. 2000. Arthropod Populations in Early Soybean Production Systems in the Mid-South. Environmental Entomology 29: 312-328.

Carrillo, M. A., Koch, R. L., Burkness, E. C., Bennett, K., Ragsdale, D. W. and Hutchison, W. D. 2005. Supercooling Point of Bean Leaf Beetle (Coleoptera: Chrysomelidae) in Minnesota and a Revised Predictive Model for Survival at Low Temperatures. Environmental Entomology 34: 1395-1401. 
Dawn, H. G., Michael, O. W., Allen, K., Greg, C. and Carl, P. 1999. Managing Soybean Insects. Texas Agricultural Extension Service, B1501.

Fehr, W. R., Lawrence, B. K. and Thompson, T. A. 1981. Critical stages of development for defoliation of soybean. Crop Science 21: 259-262.

Hammack, L., Pikul Jr, J. L. and West, M. S. 2010. Phenology and Abundance of Bean Leaf Beetle (Coleoptera: Chrysomelidae) in Eastern South Dakota on Alfalfa and Soybean Relative to Tillage, Fertilization, and Yield. Environmental Entomology 39: 727-737.

Hammond, R. B., Higgins, R. A., Mack, T. P., Pedigo, L. P. and Bechinski, E. J. 1991. Soybean Pest Management, pp.341-472. In CRC Hand Book of Pest Management in Agriculture, 2nd ed. Boca Raton, Florida (PIMENTEL D., Eds.).

Hesler, L. S., Prischmann, D. A. and Dashiell, K. E. 2012. Field and Laboratory Evaluations of Soybean Lines Against Soybean Aphid (Hemiptera: Aphididae). Journal of Economic Entomology 105: 608-615.

Higley, L. G. and Boethel, D. J. 1994. Handbook of soybean insect pests. Entomological Society of America, Lanham, MD.

Hunt, T. E., Higley, L. G. and Witkowski, J. F. 1994. Soybean growth and yield after simulated bean leaf beetle injury to seedlings. Agronomy Journal 86: 140-146.

Koch, R. L., Porter, P. M., Harbur, M. M., Abrahamson, M. D., Wyckhuys, K. A. G., Ragsdale, D. W., Buckman, K., Sezen, Z. and Heimpel, G. E. 2012. Response of Soybean Insects to an Autumn-Seeded Rye Cover Crop. Environmental Entomology 41: 750-760.

Krell, R. K., Pedigo, L. P., Hill, J. H. and Rice, M. E. 2004. Bean leaf beetle (Coleoptera: Chrysomelidae) management for reduction of bean pod mottle virus. Journal of Economic Entomology 97: 192-202.

Lam, W. K. F., Pedigo, L. P. and Hinz, P. N. 2001. Population dynamics of bean leaf beetles (Coleoptera: Chrysomelidae) in central Iowa. Environmental Entomology 30: 562-567.

Lam, W. F., Pedigo, L. P. and Hinz, P. N. 2002. Spatial distribution and sequential count plans for overwintering bean leaf beetles (Coleoptera: Chrysomelidae). Journal of Agricultural and Urban Entomology 19: 73-84.

Obopile, M. and Hammond, R. B. 2001. Effects of Delayed Harvest on Soybean Seed Quality following Bean Leaf Beetle (Coleoptera:Chrysomelidae) Pod Injury. Journal of Kansas Entomological Society 74: 40-48.

SAS Institute. 2004. SAS/STAT User's Guide, Version 9.1.4. SAS Institute, Cary, NC.

Smelser, R. B. and Pedigo, L. P. 1991. Phenology of Cerotoma trifurcata on soybean and alfalfa in central Iowa. Environmental Entomology 20: 514-519.

Srinivas, P., Danielson, S. D., Smith, C. M. and Foster, J. E. 2001. Cross-Resistance and Resistance Longevity as Induced by Bean Leaf Beetle, Cerotoma trifurcata and Soybean Looper, Pseudoplusia includes, herbivory on Soybean. Journal of Insect Science 1: 5.

Witkowski, J. F. and Echtenkamp, G. W. 1996. Influence of planting date and insecticide on the bean leaf beetle (Coleoptera: Chrysomelidae) abundance and damage in Nebraska soybean. Journal of Economic Entomology 89: 189-196. 
Zheng, C., Chen, P., Hymowitz, T., Wickizer, S. and Gergerich, R., 2005. Evaluation of

Glycine species for resistance to bean pod mottle virus. Crop Protection 24:49-56.

Table 1. Mean number of bean leaf beetle per plant in 2004 and 2005 at different planting dates

\begin{tabular}{cccc}
\hline \hline \multirow{2}{*}{ Date } & Planting & Season & \multicolumn{2}{c}{ Mean \pm SE } \\
\cline { 3 - 4 } & & & Butterbeans \\
May 20 & 2004 & $1.08 \pm 0.06 \mathrm{a}$ & $0.71 \pm 0.15 \mathrm{a}$ \\
June 3 & 2004 & $1.34 \pm 0.05 \mathrm{a}$ & $0.91 \pm 0.07 \mathrm{~b}$ \\
& & & \\
May 18 & 2005 & $0.87 \pm 0.03 \mathrm{a}$ & $0.53 \pm 0.04 \mathrm{~b}$ \\
May 31 & 2005 & $0.76 \pm 0.04 \mathrm{a}$ & $0.62 \pm 0.04 \mathrm{a}$ \\
\hline
\end{tabular}

* Means for each date within a row followed by the same letter are not significantly different $(\mathrm{P} \leq$ $0.05)$

Table 2. Mean number of bean leaf beetle per plant for 2004 and 2005 first planting date growth stages

\begin{tabular}{lcccc}
\hline \hline Plant stage & \multicolumn{2}{c}{ 2004 Mean \pm SE } & \multicolumn{2}{c}{ 2005 Mean \pm SE } \\
\hline & Butterbeans & Envy & Butterbeans & Envy \\
V3 & $1.70 \pm 0.20 \mathrm{a} \mathrm{A}$ & $0.00 \pm 0.20 \mathrm{~b} \mathrm{C}$ & $0.66 \pm 0.09 \mathrm{a} \mathrm{B}$ & $0.00 \pm 0.13 \mathrm{~b} \mathrm{D}$ \\
V4 & $1.80 \pm 0.14 \mathrm{a} \mathrm{A}$ & $1.30 \pm 0.20 \mathrm{a} \mathrm{A}$ & $1.20 \pm 0.09 \mathrm{a} \mathrm{A}$ & $0.60 \pm 0.09 \mathrm{~b} \mathrm{C}$ \\
V5 & $1.40 \pm 0.20 \mathrm{a} A$ & $1.20 \pm 0.14 \mathrm{a} \mathrm{A}$ & $1.45 \pm 0.13 \mathrm{a} A$ & $1.00 \pm 0.09 \mathrm{a} \mathrm{B}$ \\
V6 & $1.80 \pm 0.20 \mathrm{a} \mathrm{A}$ & $1.30 \pm 0.20 \mathrm{a} \mathrm{A}$ & $1.31 \pm 0.13 \mathrm{a} \mathrm{A}$ & $1.33 \pm 0.13 \mathrm{a} \mathrm{A}$ \\
R1 & $1.75 \pm 0.14 \mathrm{a} \mathrm{A}$ & $1.37 \pm 0.12 \mathrm{a} \mathrm{A}$ & $1.33 \pm 0.09 \mathrm{a} \mathrm{A}$ & $1.16 \pm 0.08 \mathrm{a} \mathrm{AB}$ \\
R3 & $0.65 \pm 0.14 \mathrm{a} \mathrm{B}$ & $0.70 \pm 0.14 \mathrm{a} \mathrm{B}$ & $0.41 \pm 0.08 \mathrm{~b} \mathrm{~B}$ & $0.73 \pm 0.09 \mathrm{a} \mathrm{C}$ \\
R4 & $0.43 \pm 0.10 \mathrm{a} \mathrm{B}$ & $0.50 \pm 0.14 \mathrm{a} \mathrm{B}$ & $0.00 \pm 0.08 \mathrm{a} \mathrm{C}$ & $0.00 \pm 0.09 \mathrm{a} \mathrm{D}$ \\
R5 & $0.17 \pm 0.08 \mathrm{a} \mathrm{B}$ & $0.00 \pm 0.12 \mathrm{a} \mathrm{C}$ & $0.38 \pm 0.07 \mathrm{a} \mathrm{B}$ & $0.00 \pm 0.08 \mathrm{~b} \mathrm{D}$ \\
R6 & $0.00 \pm 0.20 \mathrm{a} \mathrm{B}$ & $0.00 \pm 0.14 \mathrm{a} \mathrm{C}$ & $1.08 \pm 0.09 \mathrm{a} \mathrm{A}$ & $0.00 \pm 0.13 \mathrm{~b} \mathrm{D}$ \\
\hline
\end{tabular}

* Means within a column of the same year followed by the same capital letter are not significantly different $(\mathrm{P} \leq 0.05)$.

* Means for each plant stage within a row followed by the same small letter are not significantly different $(\mathrm{P} \leq 0.05)$. 
Table 3. Mean number of bean leaf beetle per plant for 2004 and 2005 second planting date growth stages

\begin{tabular}{|c|c|c|c|c|}
\hline \multirow[t]{2}{*}{ Plant stage } & \multicolumn{2}{|c|}{2004 Mean \pm SE } & \multicolumn{2}{|c|}{2005 Mean \pm SE } \\
\hline & Butterbeans & Envy & Butterbeans & Envy \\
\hline V1 & $1.30 \pm 0.22 \mathrm{a} A B$ & $0.00 \pm 0.22 \mathrm{~b} \mathrm{D}$ & $0.69 \pm 0.08$ a D & $0.70 \pm 0.11 \mathrm{a} \mathrm{B}$ \\
\hline $\mathrm{V} 2$ & $1.75 \pm 0.16 \mathrm{a} \mathrm{AB}$ & $1.70 \pm 0.22 \mathrm{a} A$ & $1.15 \pm 0.08 \mathrm{a} \mathrm{BC}$ & $0.73 \pm 0.11 \mathrm{a} \mathrm{B}$ \\
\hline V3 & $2.05 \pm 0.16 \mathrm{a} \mathrm{A}$ & $1.60 \pm 0.16$ a A & $1.38 \pm 0.08 \mathrm{a} \mathrm{AB}$ & $1.11 \pm 0.08 \mathrm{a} \mathrm{A}$ \\
\hline V4 & $2.12 \pm 0.16 \mathrm{a} A$ & $1.70 \pm 0.16 \mathrm{a} A$ & $1.50 \pm 0.08 \mathrm{a} \mathrm{A}$ & $1.28 \pm 0.08 \mathrm{~b} \mathrm{~A}$ \\
\hline V5 & $1.90 \pm 0.16 \mathrm{a} \mathrm{AB}$ & $1.48 \pm 0.22 \mathrm{a} \mathrm{A}$ & $0.90 \pm 0.08 \mathrm{~b} \mathrm{CD}$ & $1.38 \pm 0.11 \mathrm{a} \mathrm{A}$ \\
\hline V6 & $1.80 \pm 0.22 \mathrm{a} \mathrm{AB}$ & $1.30 \pm 0.22 \mathrm{a} \mathrm{AB}$ & $0.00 \pm 0.11 \mathrm{~b} \mathrm{E}$ & $1.20 \pm 0.11 \mathrm{a} \mathrm{A}$ \\
\hline $\mathrm{R} 1$ & $0.65 \pm 0.16 \mathrm{a} \mathrm{C}$ & $0.85 \pm 0.16$ a BC & $0.00 \pm 0.08 \mathrm{~b} \mathrm{E}$ & $0.78 \pm 0.08 \mathrm{a} \mathrm{B}$ \\
\hline R3 & $0.00 \pm 0.22 \mathrm{~b} \mathrm{D}$ & $0.60 \pm 0.16$ a CD & $0.00 \pm 0.08$ a $\mathrm{E}$ & $0.00 \pm 0.08$ a C \\
\hline $\mathrm{R} 4$ & $0.40 \pm 0.13$ a CD & $0.15 \pm 0.16$ a CD & $0.25 \pm 0.08$ a $E$ & $0.00 \pm 0.08 \mathrm{~b} \mathrm{C}$ \\
\hline $\mathrm{R} 5$ & $1.18 \pm 0.12 \mathrm{a} \mathrm{B}$ & $0.32 \pm 0.10 \mathrm{~b} \mathrm{CD}$ & $1.04 \pm 0.06$ a CD & $0.05 \pm 0.07 \mathrm{~b} \mathrm{C}$ \\
\hline R6 & $1.63 \pm 0.22 \mathrm{a} \mathrm{AB}$ & $0.30 \pm 0.16 \mathrm{~b} \mathrm{CD}$ & $0.95 \pm 0.11 \mathrm{a} C D$ & $0.64 \pm 0.07 \mathrm{~b} \mathrm{~B}$ \\
\hline
\end{tabular}

* Means within a column of the same year followed by the same capital letter are not significantly different $(\mathrm{P} \leq 0.05)$.

* Means for each plant stage within a row followed by the same small letter are not significantly different $(\mathrm{P} \leq 0.05)$.

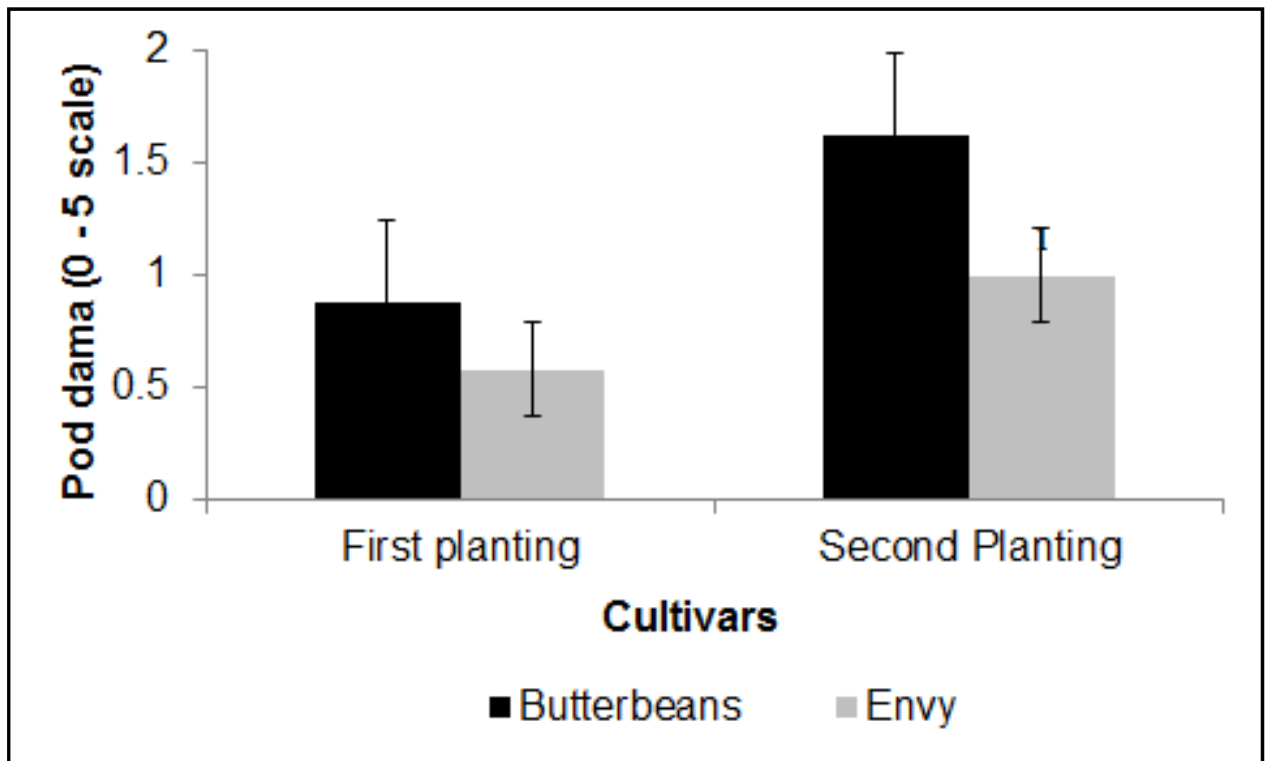

Figure 1. Mean pod damage ratings for C. trifurcate in 2004. Pod damage rating of 0 referred to plants with no pod damage, 1 those with $\leq 5 \%$ pod damage, 2 those with $\leq 10 \%$ pod damage, 3 those with 11 to $\leq 20 \%$ pod damage, 4 those with 21 to $\leq 40 \%$ pod damage and 5 those with $\geq 41 \%$ pod damage. 


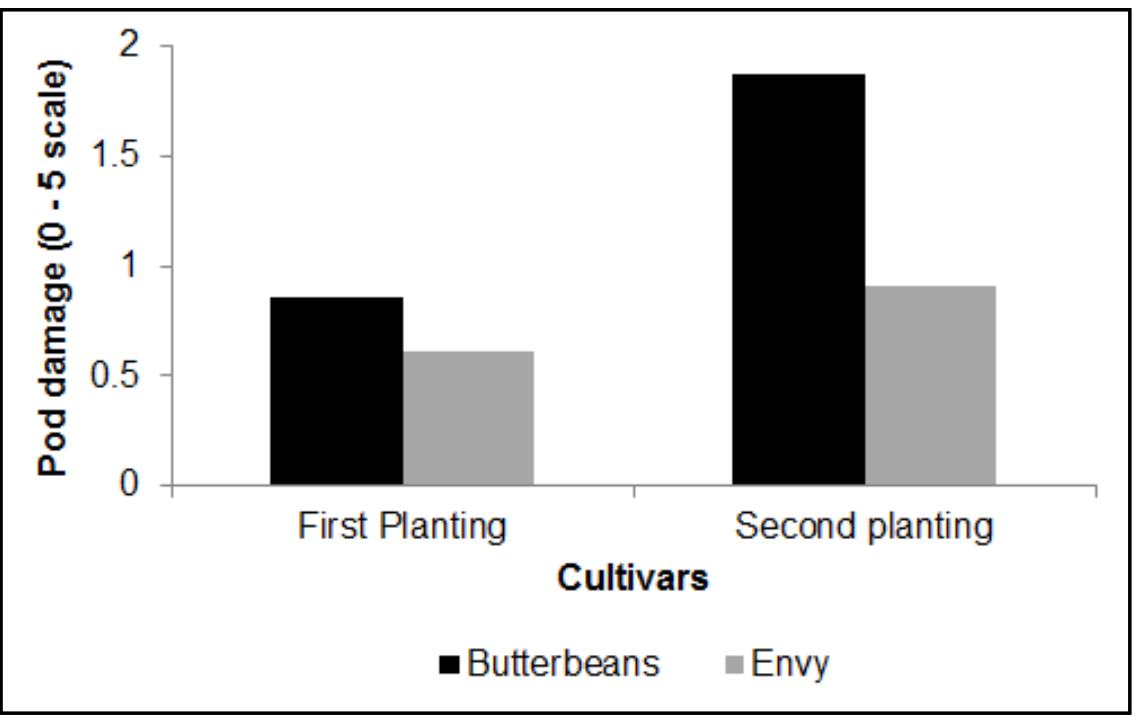

Figure 2. Mean pod damage ratings for C. trifurcate in 2005. Pod damage rating of 0 referred to plants with no pod damage, 1 those with $\leq 5 \%$ pod damage, 2 those with $\leq 10 \%$ pod damage, 3 those with 11 to $\leq 20 \%$ pod damage, 4 those with 21 to $\leq 40 \%$ pod damage and 5 those with $\geq 41 \%$ pod damage. 